\title{
Money as a Total Social Fact in Argentinean 2001/02 Crisis and in its Resolution(*)
}

\author{
A Moeda como Fato Social Total na Crise \\ Argentina de 2001/02 e na sua Resolução
}

Jaime Marques Pereira ${ }^{(*)}$

\begin{abstract}
Resumo: Este artigo contrapõe às explicações institucionais das reversões repentinas de antecipações, tal como foi o caso da crise argentina de 2001/2002, uma análise revelando a crise do dispositivo de confiança na moeda nacional, assim conceitualizada como fato social total. Com base nesta visão multidimensional (econômica, política e simbólica) das funções da moeda, mostra-se que o risco sistêmico do endividamento público na origem da crise resulta de promessas ilusórias de ganhos futuros, assentadas na teoria nova clássica e pelas quais se armaram os compromissos políticos que sustentaram o regime monetario de currency board. A resolução desta crise permitiu redefinir um regime mais distributivo inspirado na teoria neo-keynesiana sem eliminar, no entanto, o risco sistêmico. A conclusão aponta a validade mais geral desse resultado na atual crise mundial ao destacar a responsabilidade da teoria neoquantitativa da moeda como representação da economia conformando a ação coletiva.
\end{abstract}

\begin{abstract}
This paper opposes to the institutional explanations for sudden reversals of expectations, as was the case in the Argentinean crisis 2001/2002, an analysis revealing a crisis of the trust set in national currency, so conceived as total social fact. Based on this multidimensional view (economic, political and symbolic) of the money functions, we show that the systemic risk of the public debt results from the illusions fostered by new classical theory on promises of future income founding the political compromises sustaining the currency board monetary regime. The resolution of this crisis has given room to a more distributive regime inspired in new-keynesian theory but not to the elimination of this systemic risk. The conclusion points out in the present context of world crisis the more general validity of this issue focusing the responsibility of neoquantitative theory of money as a representation of economy performing collective action.
\end{abstract}

(*) This text has been presented in last 2009 Sase conference, IEP, Paris, july 2009. A larger version of this article had been publisched in French, "Economie et institutions", n. 10-11, 2007. I would like to thank the "Institut Caisse des dépôts et consignations pour la recherche" for the financial support of this research.

(**) Professor da Université de Picardie Jules Verne —CRIISEA. E-mail: $<$ jmarquespereira@noos.fr $>$ Recebido em 5.4.2011 e aceito em 14.10.2011. 


\section{INTRODUCTION}

Starting from the vision of money as total social fact, this work studies the 2001/2002 Argentine monetary crisis as a coordination crisis. It re-examines in this way the question of market adjustments at the level of the money functions' integration.

The setting of a definition of money as a total social fact poses the unit of account as a variable and not as a data. The account function may in this way be studied as an organizer of the price system: it specifies how prices depend on the confidence into money, operating in credit and titles' evaluation. The information delivered by prices is therefore a coordination of knowledge about the economy (the plans of agents). The object of the anticipation cannot from then be reduced to a simple calculus of futures' utilities. It's about interpretations - the economy is a hermeneutic. Reversals of anticipations operating in a financial crisis must be, in this sense, defined as reevaluations revealing erroneous interpretations.

This analytical grid of a particular systemic crisis shows what it has in common with other cases: an ignorance of the systemic risk at the basis of distributive compromises constitutive of a monetary regime. These compromises are about promises of revenues that economic theory justifies. In this cognitive performance, the neo-quantitative theory of money is the lever of a major institutional change as to the governing of anticipations.

The monetarist norm was in Argentina a social faith. In the 2001/2002 crisis, it suddenly became a central object of the public debate. This reveals the practical senses of the norm, what each one attributes to the norm and that, in this manner, guides its actions. Capital flees, which triggers the collapse of the payment system, appears to be immoral. Beyond political responsibilities, the crisis highlights the responsibility of a belief — the necessary neutrality of money. In practice, leaving to markets the power of monetary issuance has excluded from the field of vision of decision-makers the monetary dangers of over-indebtedness. The economic theory is, in the very same way, indirectly responsible for the crisis.

The acting of a theory is here its performance to establish the governing upon the maintained ignorance of systemic risk. Beyond diverse forms of over-indebtedness, this ignorance may be described as a general cognitive norm of a political logic organizing wage deflation or, at best, its contention. Before developing this analysis, we specify the methodological implication of the conceptualization of money at the basis of this interpretation of the crisis and its outcome.

\section{****}

Considered as a total social fact, money is a fundamental mechanism of society reproduction which determines its economic functions. Money in this way is defined as unit of account which symbolizes the value that objectifies in means of payments a regime of debts monnayage $e^{(1)}$. The interaction between these three functional forms of money implies

(1) The term "monnayage" still exist in French. In its common sense, it is equivalent with the offering price. By instance, for qualify the price one expects for any kind of effort. What it denotes of money creation still exists but does not appear anymore. The making of modern money is pure abstraction, since it has no more metal anchorage. One does not mint 
a contingent interdependence between account and payment community and political community.

This definition comes within the tradition that focuses the analysis of money as a debt counterpart and more precisely the fact stressed by Schumpeter (1970) on its property to express credit by a fixed nominal value. Money makes the operation of a bank balancesheet a social accountability of each individual contribution to the creation of wealth and of the part of it he can claim. O. Lakomski-Laguerre (2004) points out the limits to this analysis: the essence of money as institution of this accountability implies the consideration of the existence of an authority defining «legal money» and its convertibility into central money. In this sense, it is in money itself that lies the power of coordination that Schumpeter attributes to bank evaluation of enterprises' bets enabling a revival of debts and, thus, the innovating dynamic of capitalism.

The definition of money as a total social fact highlights the nature of this monetary power as sovereign power. It allows specify market's coordination through the unit of account and the creation of means of payments. So, it breaks with an instrumental vision of money functions that ignores the legitimacy of a monetary regime on which depends its permanence. It shows that this legitimacy stems from the fact that the possibility of exchanges supposes a social agreement on the convertibility of units of account, peculiar to the diverse networks of debts. We take in consideration that it exists, despite appearances, a plurality of units of account beyond currencies. This plurality is not only a plurality of issuers - for example, provincial moneys that were issued in Argentina to overcome the means of payment shortage after 1998. The plurality can be otherwise detected in the fixation of relative prices when it mobilizes various units of account. We show that desired profits are calculated in Argentina with reference to the currency. The exchange risk covering whether by inflation or by indexation - is included in sales prices, and thus determinate capital revenues.

It is then the uniqueness of a system of account that transforms money into a social accountability. It implies consequently, as much as the issuance of means of payments, a regulation power on which depends the legitimacy of the incomes' distribution. The confidence in their permanence commits the monnayage of debts. The latter is the cog where forms the coordination of decentralized decisions. In this way, the confidence translates into a pacification of the conflicts of interests inherent to promises concealed by a monetary regime.

The conciliation of interests mobilizes a cognitive function of economic theory. The nexus that it establishes between monetary policy and structural reforms marks off collective action to a representation of the economy where employment and salaries depend on the political compatibility between structural reforms and price stability ${ }^{(2)}$. This nexus is inspired by the contemporary revision of money neutrality's postulate. In this paper, we seek understand on the Argentine case how this representation of the future imposes

money but one still gets money in exchange of a debt recognition. A monetary regime regulates credit and its counterpart - the money issuance. In this sense, it seam more precise to use the expression "monnayage regime of debs", expressing clearly the fact it is related to sovereignty as signified by the ancient term monnayage.

(2) See for example the discussion on European governance (cf. Aghion and al. 2004). 
itself de facto as a coordination model in collective action where forms distributive compromises, constitutive of a regime of debts monnayage. We will analyze successively the model that establishes coordination on the reputation of rigor with the currency board issuance regime (1991-2001) and afterward the current model which coordination is based on an exchange rate said to be «competitive and foreseeable» (since 2002).

The first part of the paper identifies the mark of the postulate of money neutrality in these two types of regimes. The second deciphers its performance as a cognitive referent of illusionary incomes promises in the long term. From a comparative viewpoint, the Argentine case suggests that the committing of speculation excesses on trial in the current bank intermediation world paralysis level points out likewise the crisis of an accounting system by which over-indebtedness is the counterpart of salary regression. Only the Ponzi agent varies: households, enterprises and/or financial institutions, state.

\section{FROM INDETERMINATION OF THE MICRO/MACRO NEXUS TO INSTITUTIONAL DEFICIENCIES}

The problem of coordination has encouraged a substantial reformulation of the analysis of the relation between micro and macro-economics. Neo-classical models release some of their axioms to integrate socio-technical parameters more in accordance with the reality of contemporary economies, such as information asymmetry or increasing returns. It has then been possible to provide a more realistic representation of the economy but the question of micro/macro relation has not been elucidated. In the absence of a positive theory of collective action that includes time and money ${ }^{(3)}$, the micro/macro relation in the long term is undetermined. Reducing collective action to actuarial calculus of a representative agent for whom money is just some number only eliminates the problem.

The economist then can only resort to ad hoc hypothesis to report from the real world by partial non-unified theories and the neo-classical approach would not be more than a methodological individualism, deprived of axiomatic (Amable, Boyer and Lordon, 1995). These ad hoc hypotheses are nevertheless justified as a description of macroeconomic correlations which allow decision-makers to forecast their choices' effects. The question is then that of the persistence of prescriptive deductions from the dynamic general equilibrium model. The institutional conditions of partial equilibriums only have, indeed, a normative value in so far as the dynamic general equilibrium can hold as «true» model of the economy and the micro-institutional prescriptions (postulated) thus offer the neoclassical methodology a new axiomatic strength. Such a methodology is questionable but does not prevent it from being the foundation of authorized knowledge $\mathrm{e}^{(4)}$. Institutions that the «true» model leads to prescribe are considered as a development model. Within this

(3) To quote only decisive statements, one can recall that the question of time is posed by Arrow (1995) when he stresses the need to highlight the shaping of rules in strategic games between central bank and the public. One must also recall that, from the 1950 s, Samuelson (1956) reported the need of a social contract on money to think the long term.

(4) The qualification of authorized refers to the hegemony of neoclassical methodology in the corporative field of economists and to the cognitive referent character that acquired the theories that follow for private agents (or interests groups) and political actors. Our analysis favors the neoclassical debate, given its importance as cognitive referent of collective action, which implies the consideration of economic policy as a social communication (Théret, 1999). 
framework, only debates on the relevance of a macroeconomic smoothing of the cycle can subsist, opposing new Keynesians and the new classical economists. More recently, the empirical knowledge of the optimal sequence of institutional building defines a second rank optimum according to the political economy peculiar to each country (Rodrik, 2008).

\subsection{The NEO-Classical DEBATE OF THE 2001/2002 CRISIS: MARKET OR GOVERNMENT FAILURES?}

The micro/macro nexus explains simultaneously the success and the crisis of the Argentine economic model of the 1990s. This is an extreme version of the model of coordination by the reputation of rigor. The rigor of the currency board regime ${ }^{(5)}$ combines with a Big Bang of liberalizations. The systemic risk that was generated by external indebtedness on which is going to depend monetary creation was only perceived ten years later when the sudden end to external financing caused a run on banks. The 2001/2002 crisis has raised a debate the international resonance of which pointed out that its interpretation could lead to recognize the limits of main stream theory (Sgard, 2004): the tragic end to the experience was indeed proven to be hardly attributable to the failure to complete the most fundamental structural reforms and therefore raised the question of a coordination failure by market forces.

An absence of monetary austerity could not be questioned but the lack of budgetary adjustment to the lowering of incomes could explain why the flight of capital had not been reversed as in 1995 with the contagious effect of the Mexican crisis. Prominent economists who had been compromised in the Convertibility plan's defense had to attribute, in this logic, the Argentine crisis to budgetary laxness. The IMF research director on Latin America, M. Mussa (2002), and the World Bank vice-president, A. Krueger (2002), set the tone for those analysis exempting the coordination by market forces from any fundamental responsibility ${ }^{(6)}$ : the thesis of the indebtedness intoxication of the Argentine government, that the debate retained from M. Mussa contribution, echoes Krueger's proposition that an international court be established that would arbitrate the bankruptcies of states.

The budgetary laxness hypothesis was demolished through the analysis of the effects on the real exchange rate, peculiar to a currency board regime. The worsening of the budget deficit was only the result of real exchange revaluation, linked to the growth of public debt. The Haussman and Velasco model (2002) reports this interaction and clearly explains this dead-end of the Argentine economy: «to grow, it had to risk accumulating a debt up to the insolvency point ; to ensure external balance, the economy had to bear a strong fall that also lead to insolvency (quoted by Boyer, 2004: 691). The dead-end expresses an "original sin" paid by the impossibility of international funding, written/drawn in local currency (Eichengreen and Haussmann, 2003).

(5) The monetary basis is limited to its currencies' counterpart. The norm is inscribed in the convertibility law.

(6) In the same perspective, the insufficiency of labor market reforms that would have limited the adjustment was also considered (Krueger, 2002; Feldstein, 2002, quoted by Sgard, op. cit.) The argument was swept by the IMF study (2004) calculating the fall of labor unit costs at 20\% from 1994 to 1998. 
Another explanation focused on an inconsistency of long term anticipations (Heymann, 2002) - agents were wrong about growth potential depending on competitive gains. The coordination failure by market forces, that sudden reversal of anticipations, indicates, could nevertheless be attributed to contracts insecurity over time, which would have had to be reduced through legal reforms, fiscal responsibility, and deposits insurance (Galliani, Heymann and Tomasini, 2003). What matters in this approach is the inconsistency of anticipations. J. Sgard demonstrates this, reminding us that the lowering of saving rates as compared to its historical average points out that the agents do not have a so-called Ricardian behavior that should, in theory, be verified, that thus anticipatively invalidated any possibility of observing a lowering of public spending balanced by an increase in private spending. He also invokes investment weakness during the period compared to its historical trend, established on the basis of cautious hypotheses taken from a neoclassical model of growth (Kydland and Zaragaza, 2002).

The opposition of interpretations is nonetheless dissolved because, as Sgard stresses it, they all can reconcile on the diagnosis of B. Eichengreen (2002, quoted by Sgard, op. cit.) that the currency board regime failure in Argentina is in fine not to have managed to give place to a «reforms forum». The responsibility would then be primarily political

\subsection{ECONOMIC POLICY AND ANTICIPATIONS IN THE CRISIS EXIT}

The coordination question has not been at the heart of the debate on the end of the crisis. It, nevertheless, is demonstrated to be central in the success of measures that rapidly checked depression and later pushed growth well beyond what allowed the providential turnaround in the international economic situation. The analysis from D. Heymann (2006) quoted above is an exception. It strives to identify very precisely the behaviors that monthly and quarterly ${ }^{(7)}$ series suggest, to explain how economic policy was able to reduce private and public indebtedness, raised by the convertibility law repeal, in tuning the control of the liquidity of the economy, of global spending and of public incomes. The author defends the thesis that this success would have resulted from the acceptance of the peso as denominator of current exchanges thanks to a monetary policy, qualified as "flexible but cautious".

The fact is empirically identifiable in the control of the peso depreciation after the abandonment of parity. The acceptation of a devaluated peso as the unit of account of exchanges nevertheless mobilizes institutional changes that get away from neoclassical prescriptions. The so called "asymmetrical pesification" and the unilateral proclamation of default constitute a violation of contracts which, at that time, has lead most main stream economists to forecast a worsening of the crisis $^{(s)}$.

The first measure allowed the conversion of a large part of deposits at the rate of 1 for 1.4 and of bank credits at the rate of 1 for 1 . The effect of this disparity on banks' balance sheets has been covered by public titles. The time deposits have been indexed on

(7) These series are easily consultable, this report being accessible on the ECLAC-Buenos Aires website.

(8) Admittedly, the default may have been advocated by some renowned economists (cf. Sgard, op. cit.). Under inventory reserve, the theoretical question that he raises in terms of discretion norm has nevertheless not been discussed. 
the CPI (consumer price index) and, subsequently, offered the possibility to convert them into public titles. The exchange market liberalization will imply a depreciation that will exceed the rate of 4 pesos for 1 dollar. The national currency later revalues to stabilize quickly around 3 for 1 . The discretionary redefinition of monetary assets and liabilities' nominal value has avoided the collapse of the banking system while the unilateral suspension of public debt service has prevented the depreciation from provoking the state's bankruptcy ${ }^{(9)}$. It was then possible to trigger a virtuous macro-economy only a few months after the enactment of these measures at the beginning of 2002.

The depression of GDP, $-10.2 \%$ on the whole year of 2002, has gradually bended. The decline in private consumption slowed from the second quarter and industrial production recovery began during the third quarter. D. Heymann explains this inflection by the complementarities between monetary policy and the abrupt external adjustment.

The threat of an explosive drift of inflation would have been controlled by the convergence of conducts of the private agents and the authorities. The former "dissociate their refusal of keeping funds in the financial system and their money demand decisions; more precisely, they have not dollarized their liquid assets for transactions, nor the prices' denominator of current exchanges". As to the authorities, their fear of a high inflation strongly incited them to "adopt a monetary and macroeconomic management that induces prospects of sufficient stability to allow, among other objectives, the making of contracts on not too short terms" (Heymann, 2006, p. 53)

Depreciation entails a collapse of imports which quickly generates a significant trade surplus. The recovery in tax collect that follows is supported by the increase in nominal receipts, while salaries and civil servants' pensions are not indexed. It is, furthermore, fed by tax on exports in which growth is favored simultaneously by devaluation and the increase in demand implying that of prices. The budget deficit thus quickly becomes a surplus. These new macroeconomic equilibriums are consolidated by monetary and exchange policy. Currencies purchase against central bank titles slows the exchange rate appreciation that would have reduced price-competitiveness. The accumulation of partially sterilized reserves of exchange and the debt restructuring in $2005^{(10)}$ reinforced the anticipation of a strong growth continuation based on a competitive and foreseeable exchange rate. Since 2003, the rate of growth has stayed at around $7 \%$. During the period, the investment rate grew more rapidly than the private saving rate but the national saving rate, fed by budget surplus, covered the difference.

Heymann does not see in the increase of saving and investment rates a sign of long term growth anticipation because the economy would henceforth find itself confronted with the inertia of an inter-temporal choice favoring consumption over future gains. Given

(9) Otherwise, while States' liabilities represented $4.1 \%$ of GDP on the eve of devaluation, they would have increased in 3 years of 9 to 11 points, according to a simulation established according to the stabilized exchange rate (Damill, Frenkel and Rapetti, 2007)

(10) The conversion of public debt into default, that creditors have accepted, cuts its dollar value of $56.2 \%$. The service of this debt is reduced from 10,175 millions US $\$$ on 31.12 .2001 to 3,205 on 18.3 .2005 , date of the issuance of the new titles. This reduction of public debt cost has however for counterpart the capitalization of interests payable from the 11 th year (Lo Vuolo and Seppi, 2008). For the official numbers, see AGN, 2006. See also, for an analysis in historical perspective, Damill and al., op. cit. 
the Argentine productive structure, the author considers that arise a problem of incentives to invest in production exposed to foreign competition, especially the one of agricultural goods as they are at the same time wage goods.

\section{Anticipations, MONey And THE Systemic RisK CYCle}

The common denominator of current exchanges does not have the neutrality ascribed by an explanation of the way out of the crisis related to the cautious flexibility of a monetary policy. In this explanation, the former denominator is kept because of its capacity to be, according to the general equilibrium model, a means of payment that is considered as the ultimate $(n+1)$ good, serving as standard. We will consider that this denominator is also act to denominate and that the efficiency of monetary policy is, for this reason, linked to the sense that the monetary sign conveys in a price setting.

The language of the economy — communication by prices - has to be viewed as a social production of sense that matches a signifier with a referent, as shown by a sociological approach to money ${ }^{(11)}$. The sign is thus not neutral, neither in the posting of prices, or in the formation of macroeconomic equilibriums. Behind gains probability, the incentives' challenge implies distributive compromises on the capacities of spending, of private and public debts liabilities and servicing, which model the monetary regime.

The analysis that we now develop of the monetary regime considers it as the result of an agreement on the monnayage of debts. The rule articulates the generic properties of money that are account and payment. The compromise on the rule (and its opposition) makes of these properties some functional forms of their use. This one is at the same time economical, political and symbolical, which signals the existence of money under three different states. The incorporated state of the value sign exists at the same time as the objectified state by a payment instrument gaining thus commodity status. The former and the latter states are the two faces of money (so-called pure number and issuer's signature). They can exist because money also exists at instituted state by a rule of debts monnayage $\mathrm{e}^{(12)}$.

Rather than keeping with an instrumental vision of money functions, one thus has to consider existing states of money that are linked by the fact of taking simultaneously functional forms peculiar to the symbolical system - the account, to the political system - the monnayage, and to the economical system - the payment. In this interaction, society constitutes and reproduces itself, which means that money is a total social fact, in the sense suggested by Mauss. This analysis characterizes the determinants - contingents to each particular society in a given historical period - of the forms of collective confidence in money, qualified as methodical, hierarchical and ethical.

(11) Following B. Théret, its essential contribution to economic analysis is to show that money is a system of generalized communication by the fact it is a "special language" that permits to undertake in confidence economic and social transactions.

(12) This conceptual device is not a set of postulates but a theoretical result of a multidisciplinary analysis that establishes the permanence of these generic properties of money beyond its functional forms, varying along the history of civilization (Théret, 2007). 
The matrix formalization that B. Théret (2008) proposes with regard to the interaction of money functional forms specifies in this context their autonomy and interdependence defining its structure as total social fact. Autonomy means that each state of money has a peculiar functional form and interdependence that this peculiar state is, as such, equally active in the other functional forms; which is featured by the matrix of these interactions in the currency board regime and in the current regime (see table 1 and 2 forward).

The usefulness of specifying forms of confidence is to circumscribe the observation field of an analysis applied to money as «abstract expression of the collectivity (...) that conditions the mental structures of individuals by mediating their actions» (Aglietta and Orléan, 2002: 102-103). In analysis of concrete situations, it allows the linking of research results of diverse disciplines to characterize the mediation in question instead of postulating it.

\subsection{From the Restoration to the RUIN Of CONFIDENCE}

The convertibility law grants legal tender to the dollar and the peso at the same time. The point was to see if, through putting it in competition with the dollar, the national currency would again become able to ensure the unit of account and the value reserve functions. The model of coordination through rigor has served of theoretical justification of such a bet and optimistic anticipations that resulted from it were considered as a proof of its relevance. Under disinflation and growth, postulates at the basis of the model could be hold as a correct approximation of reality.

Yet it is the distance from reality, as much of the model as of its discourse, that made the bet playable. Numerous analyses indeed suggest that public decision-makers seemed perfectly conscious that optimism depended on this distance. Hypotheses of money neutrality, of competition efficiency, and of uniform rational anticipations are the convertibility Plan's cognitive referent. Its justification guides collective action but this one is not-far from it - in line with what the model prescribes. Hypotheses of the model structure the language of the communication policy, making it received as true.

\subsubsection{The MOdel and its Language/Discourse}

To win the bet of the adhesion of all to a new national unit of account, what primarily mattered was the model language. It refers to the credibility of the monetary regime to ethical and social values of liberalism. More precisely, we can say that it formulates the belief in a restructuring of the nation that makes it a market society, able to make good use of globalization thanks to money which quality makes it equal to the dollar.

The government agenda of the institutional transformation of the economy provided all the advertising required to this political will. Naming of «convertibility Plan» echoes the law designation instituting a bi-monetary regime. The discourse identifying the good quality of money to its ability to resist the dollar competition changed the fixed parity into a relative prices language that refers them implicitly to the vision of justice, associated to the values of market freedom imposing them with globalization. 
An interview with an advisor of Domingo Cavallo, made the day before his nomination as Minister of Finances, suggests how the convertibility Plan and its communication policy were conceived (Roig, 2008). It specifies the subliminal message of the new system of account. This analysis of the interview reveals this strategic aspect of beliefs in the symbolical load conveyed by the political slogan "making a clean sweep of the past through money that is born 'healthy', because it was submitted to the dollar competition". The discourse concentrates what one has to call, from a sociological viewpoint, the expected symbolical performance of money as a special language, that is, its capacity to guide collective action through the representation provided by economic policy.

The past, which is mentioned, is the referent of prices denominator. To make possible the stopping of a price drift, which became uncontrollable, the monetary rule must liquidate the cause that the theory had identified - the populist macro-economy (Dornbusch and Edwards, 1992). In this sense, making a clean sweep of the long past of compromise with inflation demands to get rid of the former conception of national development - industrialization by imports substitution.

To come to the clearance of this inheritance, the quality that the peso has to acquire does not reduce itself as a special «competitive» good, which recovers here the sense of nominal anchor, ensured in theory by its distributive neutrality. In reality, the quality of the nominal anchor has not been the one of distributive neutrality. Quite the contrary, forced parity has been the means to make possible a distributive compromise. The quality of the rule was to act on representations of social justice and economic interests (in the double sense of the term representation, as idea and as organization). It is through these representations constructed in collective action that develop the legitimacy of the monetary regime and structural reforms. The economic bet on disinflation was first a bet on symbolical and political order constitutive of a monetary regime.

\subsubsection{Profit Promises and the figure of The PeOPle}

The political and symbolical bet that the convertibility Plan committed has been won in collective action, on the one hand, through promises of profit, related to structural reforms and, on the other hand, thanks to the ideological change that legitimates the former.

Privatization is the launching pad of structural reforms. It is the cornerstone of a «business community» reconstruction (Basualdo, 2006). The sale of public enterprises resolves state bankruptcy, caused by hyperinflation. It allows simultaneously obtaining the adhesion from public debt creditors. The means was to accept that part of the payment of privatized assets was drawn on Treasury bonds at face value, while their market value had been reduced ${ }^{(13)}$. Privatizations provide the means of restoring external indebtedness. Along with capital repatriation, this allows their realization on a larger scale.

A second generation of reforms brings about a reduction of taxes on employers and provides new rules of competition. The former permits the anticipations of new monopoly

(13) This form of solving the Latin American debt crisis was advocated by international institutions since the mid 1980 s. 
rents ${ }^{(14)}$, in addition to the ones that prejudged concession contracts of collective services. The effects of trade liberalization on employment and salaries, associated with the recasting of labor laws, serve as the device intended to put the profit curve back on an upward trajectory.

Figure 1: Wage average, labour productivity, tot. capital productivity, profit ratio. Index $1960=100$

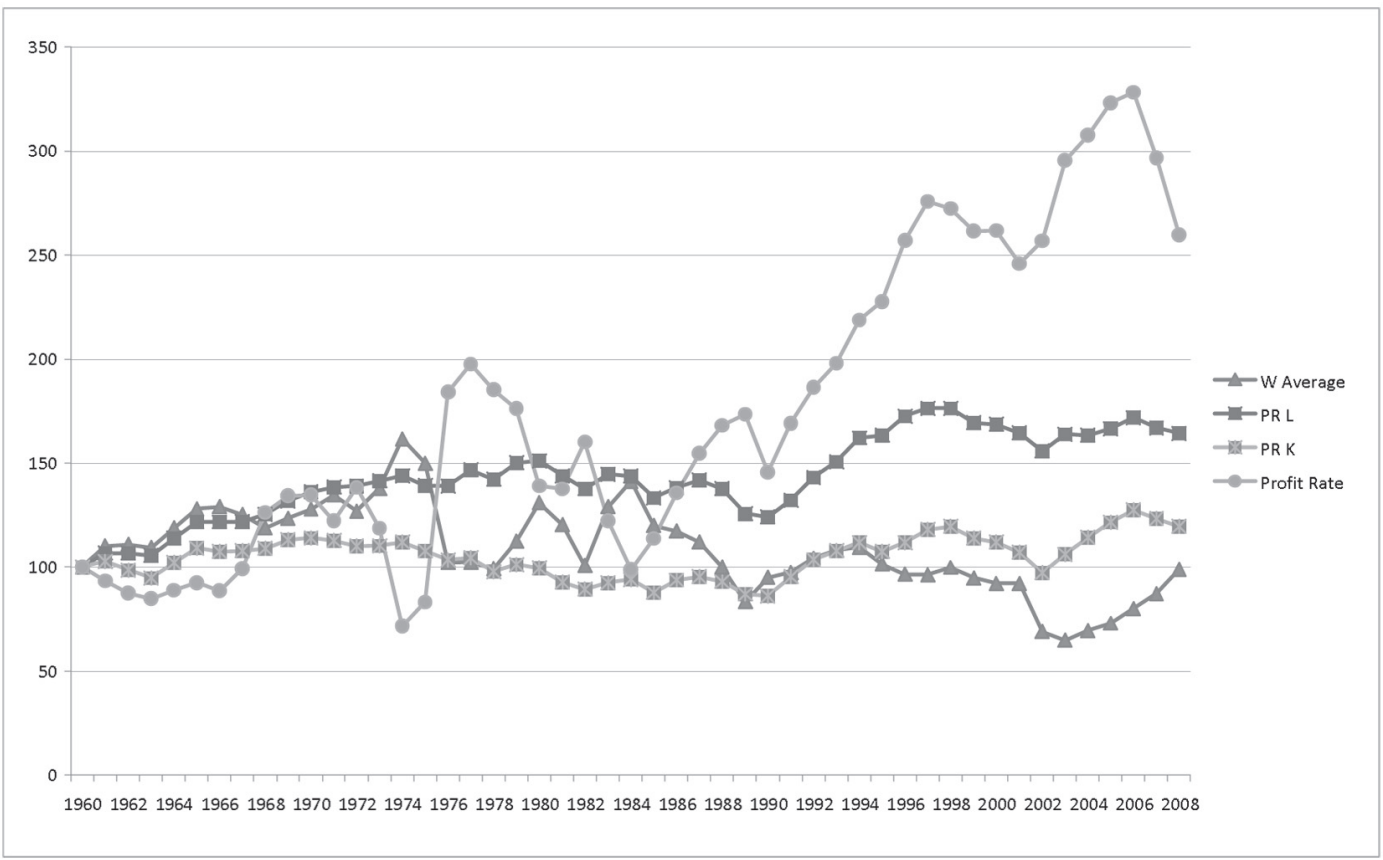

Source: CIEPP (2009), data CEPED (2007), Maia y Nicholson (2002), Llach y Sánchez (1984), CEPAL (1991) and INDEC.

Thus a business community re-joins together from the two components of capital that the work of E. Basualdo (cited above) identifies on the basis of an analysis of patrimonial restructuring since the 1970s: on the one hand, what he calls the diversified oligarchy big groups oriented toward export and financial activities and that have integrated part of the former national industrial bourgeoisie ; on the other hand, foreign capital — international banks, creditors of the public debt, and transnational corporations. The share of the former in national income had clearly fallen during the 1980 s but is going to rise in a significant manner during the 1990s. The coalition of interests between these two dominant components of capital takes shape through the revaluation of financial and physical assets. The work in question shows the productive valuation of each of these two dominant components of capital in the big firms' trading accounts. We postpone until the next section a review of the financial dimensions of this valuation because it locates external indebtedness in anticipations' reversal.

(14) There are numerous studies on the question. For an analysis of their importance in the formation of government's political coalition, see Palermo, 2004. 
From 1993 to 2000, the 500 largest firms saw their gross operating surplus increased $7.1 \%$ per year. The one of the 200 largest firms increased $8.4 \%$ during the period. GDP growth average was $4.9 \%$. These gaps are related to export activity. Thus, unlike the rest of the economy, during the whole period, the turnover of the largest firms was less affected by the cycle down-turns' years of the period (1995, 1998-2000).

On the other hand, the total salary-bill grew by only $1.7 \%$ per year. Average real salary increased by $2.2 \%$ per year from 1991 to 1994 . It subsequently collapsed while productivity continued to grow until 1998 at around $8 \%$. Productivity gains were made because of the importing of new equipment (the cost of which was decreased by the lowering of tariffs and appreciation of real exchange rate), of the new liberal labor law, and of the reorganization of production; the whole translated into an increase in the level of unemployment, the fragility of employment, and the intensification of work (Neffa, 2004).

Despite unfavorable consequences for employees in the functional distribution of income, the increase in unemployment and under-employment (these variables stabilized during second period of growth), the coalition integrated the political actors representing labor. The ability of certain unions to manage pension trust funds constituted a revealing element, although their place in the market was marginal. What matters are the consequences of the evolution of the political regime that moved from Peronism to neo-liberalism ${ }^{(15)}$. Argentina is considered as an emblematic case of "democracy by delegation", a concept that characterizes the "presidentialism" established in Latin-American democratizations (Svampa, 2007). In this type of political regime, the sovereignty of the people is limited to clienteles and corporatist mechanisms by which the individual's power is for the most part delegated to the presidential function. Without going into details of the reorganization of the Argentine political system, it is advisable to specify the transformation of Peronism as a core variable of the place of a new social justice conception in the distributive compromise that constitutes the monetary regime.

This mutation is particularly well highlighted by an analysis of the Peronist movement militants' political discourses and practices, proposed by A. Tizziani (2007). His work demonstrates how the Peronist ideology integrates protest of the economic and social policy led by the party which incarnates it. According to it, the Peronist neo-liberal metamorphosis did not damage its ability to remain identified with the people. The analysis of the discourse of Peronist militants shows their resignation to a form of legitimacy, based on a proclaimed subordination to the destiny imposed by the law of the market, which drives them to limit their militant actions to assistance to the poor by local powers. We can add that the acceptance of market law incorporates the conception of social justice as defended by contemporary economic theory (to increase the "capabilities" of the poor for economic and political integration). The both hypothesis are justified by a redefinition of collective action that legitimates market through the empowerment of the poor, as suggested

(15) The term Peronism denotes in sociological literature the social and political movement, agent of the general Peron mythical inheritance, minister of labor and later president of Argentina, who institutes universality of social rights in the 1940s. The reference to Peronism recovers however in the common sense a wider meaning that makes it the very image of people, which explains the ability of the Peronist party to incorporate the social opposition to the convertibility Plan (Tizziani, 2007) and to integrate today (see below) a significant part of social movements' leaders that represents the sectors of population not having taken advantage of current growth (Svampa, 2007). 
by A. Tizziani analysis. The Peronist government proves itself able to recast politics, domesticating the «big popular animal», recalling Rancière Platon's famous expression.

We can, in a complementary manner, put forward the hypothesis that the original Peronist utopia of social cohesion, based on a pact between classes, is replaced by that of a neo-liberal society because the former exorcises the traumatic memory of radical social conflict. The slogan «making a clean sweep of the past» amounts to the repression of the memory of the guerilla war and its bloody repression during the second half of the 1970 s. The slogan induces belief in the definitive replacement of class struggle, that leaved in the past no other governing alternative than the macro-economy of populism.

This hypothesis is developed in similar terms by L. Blaum (2007) in his analysis of economic knowledge as new form of the discourse of the Master, legitimating the system of domination. Applying to Argentina the characterization applied by J. Lacan to socialism, Blaum shows in a Marxist perspective that the economist's discourse allows the Argentine to think himself primarily as economic agent because this discourse transforms money into a symbolic process by which the commodity fetish enables him to repress past trauma. The discourse of "vulgar political economy" thus signifies, at a psychic level, that the symbolical field it marks out makes the individual discover the social purpose of the selfregulation of markets.

Considering the reconstruction of confidence in money, this analysis specifies the psychic goal related to «healthy» money discourse, that the Master loans from the economic theory of neo-liberalism. The system of account, as a symbolical system of signs, recasts the social faith in nation on the principles of individualistic values. The convertibility Plan has carried out a redefinition of the political system of subjects, which drives them to redevelop their economic actions (investment bets, labor market or informal activities insertion strategies) in the frame of a new sovereignty regime which recasts the nation on the value of the individual as economic agent.

\subsubsection{The FUnCTIONALITY OF THE IGNORANCE OF SYSTEMIC RISK}

The crisis begins when is called into question the belief that foreseeable competitive gains are the pledge of payment promises and of the revival of external debts ${ }^{(16)}$. The coherence between the new states of existence of money is going to break. It was nevertheless not a sudden reversal of anticipations, nor the general inconsistency of the former. What really matters was that the confidence in nominal anchor's stability on the long term was not as generalized as the success of the convertibility Plan induced one to believe.

E. Basualdo analysis of patrimonial restructuring cruised with external accounts permits to show that ethical confidence was in fact limited since the beginning. Indeed, it did not proceed from an instituted state of money ensuring the unity of the system of account over the long term. There is differentiation in long term anticipation between

(16) This is happening following Brazil's renunciation of exchange anchorage in 1998. The neighbor country is representing then a third of the exports. 
components of capital. The diversified oligarchy seems to have believed only in shortterm promises. It will go to rid itself of assets that commit incomes in pesos. It gradually sells back the titles of privatized enterprises and of those which are oriented toward domestic demand.

The monetary fact unity rests on a long term illusion but that this component of capital did not share but from which it thrived. Its distrust of fixed parity in long term has to be viewed, however, as a parameter in confidence building in the short and medium term and, as such, a condition of the distributive compromise constitutive of the monetary regime. This paradox brightens up in the analysis of debts composition. The expansion of foreign exchange reserves was ensured until 1995 by private external indebtedness and thereafter by public external indebtedness. The fixed parity credibility, conditioning payment promises, depended on the level of reserve. So, the key to success of the convertibility Plan to restore confidence was equally the one of its destruction.

The patrimonial restructuring is determining in the evolution of external accounts. Basualdo puts forward two observations: 1/ from 1994 to 1997, the progression in the resale of assets from which income is drawn in pesos is concomitant to capital outflows and private external indebtedness; 2 / the groups owing the 200 biggest companies have a positive contribution in trade balance since 1994 whereas the rest of the economy is responsible for its deficit. The author concludes: «When the crisis of the convertibility regime began in 1998, the capital of this component of dominant sectors was concentrated on dollarized financial assets, invested abroad and the revenues from the firms they control in the country were equally dollarized» (p. 344-345).

Expected profit from buying privatized enterprises has justified private external indebtedness because the perspective of public external indebtedness was, from the start, a pillar of methodical confidence. After 1995, public debt is the spring of hierarchical confidence: it ensures the distributive compromise permanence, even if the business community of the capital components splits between a bet on a full dollarization and a bet on a future devaluation.

The accumulation of the pessimism of anticipations since the first quarter of 2001 does not reveal any inconsistency in previous optimistic anticipations but rather that of the coordination by the market theoretical model, of which they were the expression. The postulate that market liberalization and financial development would ensure the increase of the growth potential induced at once the emergence of the systemic risks and the inability to detect it. The success of the convertibility Plan and the disaster it caused went hand in hand.

This inter-temporal incoherence of the monnayage rule had allowed the recasting of the symbolical, political, and economical society's reproduction mechanisms. In political action, the neo-liberal mutation of Peronism makes the naturalization of social relationships concrete. Their legitimacy is the condition of the incorporation of the system of account. This legitimacy thus hangs on the perpetuation of the nominal anchorage of incomes' promises. Their revaluation which leads to the crisis of payments does not only challenge an exchange regime but collective recognition of the unit of account. As this is the 
condition of the economy liquidity, total wealth and short term incomes are devaluated, with the exception of the export's sector.

It results from this a simultaneous collapse of ethical and hierarchical confidence which entails the government fall in social explosion where meets the anger of the poor and the revolt against bank withdrawal limit. The term «corralito» is eloquent: to do not dispose of its money amounts bank clients to be a cattle paddock. A crisis of external funding, while becoming a systemic bank crisis, triggered a whole society reproduction crisis because of the illusion of eternally «healthy» money that prevailed in the whole social body ${ }^{(17)}$, with the exception of a component of capital.

Table 1: The sources of confidence in a peso equal to the dollar, and of its crisis $^{(18)}$

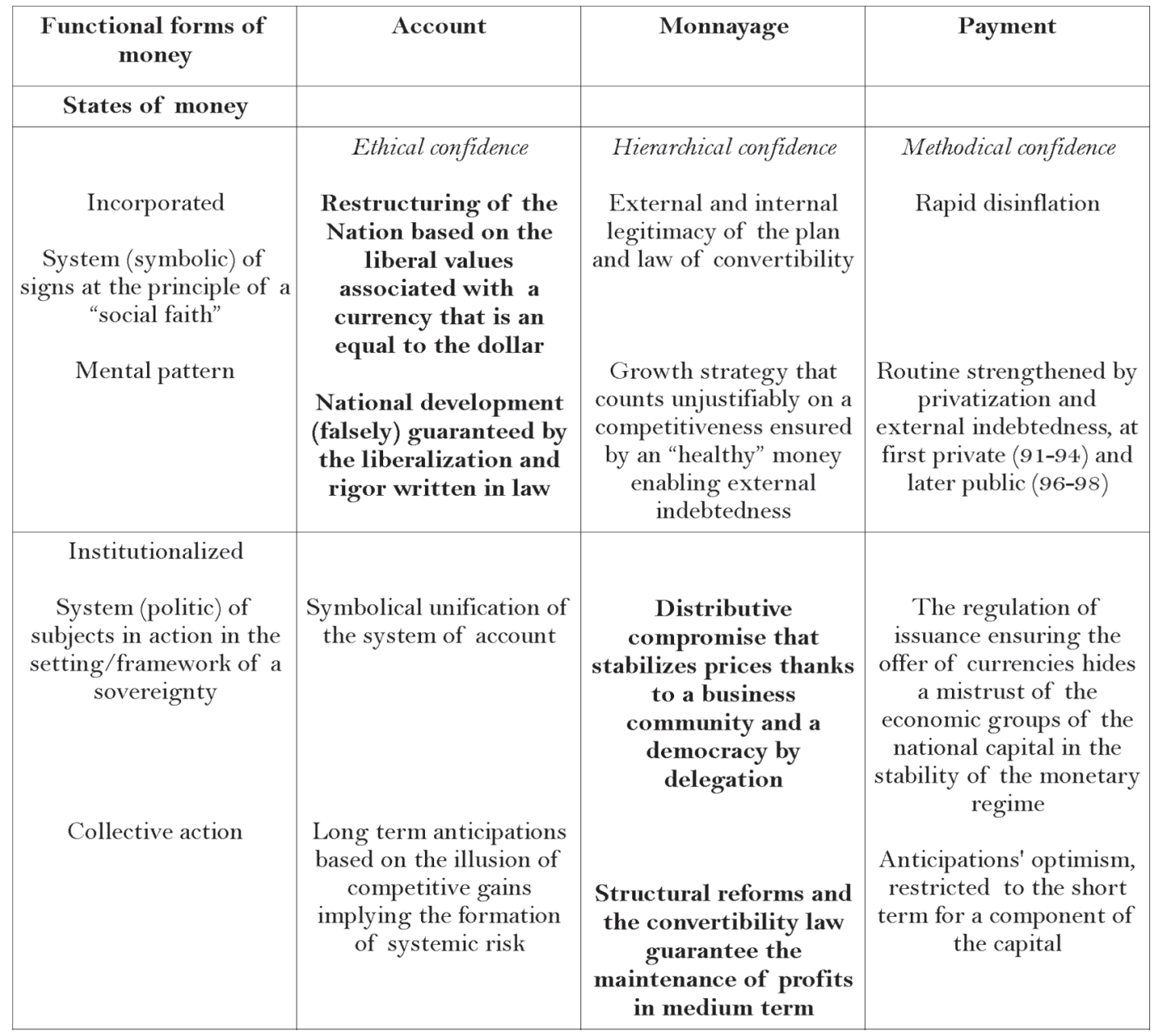

(17) The illusion's real effects spread to most disfavored groups, as shows the part that the convertibility law has been able to play in the representation of national membership of barrios' inhabitants. The word is not just a neutral administrative reference but recovers, in the common sense, a connotation of social exclusion. The discourse analysis on economical life of the barrio shows that its inhabitants perceive "convertibility" (the word belongs to common language) as a guarantee of personal credits expansion and other informal gains by which they have access to money coming from outside (Jacopin et Puex, 2002)

(18) We report in bold the basic functional form of each state of existence of money. 


\begin{tabular}{|c|c|c|c|}
\hline $\begin{array}{c}\text { Objectified } \\
\text { objects enabling the } \\
\text { circulation - renewal of } \\
\text { debts }\end{array}$ & $\begin{array}{c}\text { The Argentine peso is re- } \\
\text { established as emblem of } \\
\text { the sovereign authority } \\
\text { of a community of } \\
\text { account in appearing as } \\
\text { equal to the dollar }\end{array}$ & $\begin{array}{c}\text { The nominal anchorage } \\
\text { objectifies in currencies' } \\
\text { availability that revives } \\
\text { the promises of payment } \\
\text { of external debts }\end{array}$ & $\begin{array}{c}\text { External indebtedness, } \\
\text { private and public, } \\
\text { restructures the } \\
\text { monetary circuit that } \\
\text { enables patrimonial and } \\
\text { productive }\end{array}$ \\
Valuation principle & $\begin{array}{c}\text { The Argentine seal and } \\
\text { signature are honored } \\
\text { the macroeconomics of } \\
\text { systemic risk is ignored }\end{array}$ & $\begin{array}{c}\text { The convertibility law } \\
\text { founds the valuation on } \\
\text { external indebtedness } \\
\text { conditioning the liquidity }\end{array}$ & $\begin{array}{c}\text { The peso-dollar parity } \\
\text { guarantees the nominal } \\
\text { value of revenues until } \\
\mathbf{1 9 9 8}\end{array}$ \\
\hline
\end{tabular}

\subsection{The WAY OUT OF THE CRISIS: AN UNRESOLVED POLITICAL ECONOMY OF DISTRIBUTIVE CONFLICT}

The exit of the crisis required a recasting of the system of payments; this was realized by the unilateral suspension of public debt service, asymmetrical pesification and the lowering of real salaries to the level to which recession and inflation made them plunge (figure 1). The sovereign reformulation of the sole debt contracts and not of labor ones defines the "flexible and cautious" monetary policy. The potential distributive effects of prior redefinition of the nominal value of monetary assets have determined its efficiency but they raised an ethical question which lay at the heart of the political debate generated by the very problematic election of a new president ${ }^{(19)}$.

The refusal to negotiate the restructuring of debt with the IMF and, more broadly, the whole economic policy choices, was not only a question of monetary caution, as conceived in a pure economical sense. The conviction strength of the flexible economic policy model was to respond to the legitimacy constraint and, very particularly, to its ethical dimension. In this case, as well, the distance from the model to reality proves to be decisive.

The model re-establishes promises of incomes in the short and medium term: it draws a growth perspective based on the rise in profits and reduced unemployment. The discourse of a break with the former regime justifies a monetary reform implying the breach of contracts. The former makes the distributive compromise possible, reviving and maximizing growth thanks to the redefinition of relative prices. As a result, the possibility of public spending is revived, enabling the funding of a massive assistance plan for the poor and the repurchase of provincial moneys - two objectives which, through their stakes in provincial politics, conditioned the nation reunification as monetary territory (Théret and Zanabria, 2007).

(19) After President Fernando de la Rùa resignation on 21.12.2001, three temporary Presidents followed one another in less than two weeks, at the same time because of the crisis of political representation where acts the relationships between local powers and internal divisions to parties but also because of the absence of any consensus on the strategy to adopt. The fourth President elected by parliament, Eduardo Duhalde, the main Peronist opponent to Carlos Menem, and chief of Buenos Aires suburbs' political clientele, establishes the economic policy followed by the President elected with universal suffrage in 2003, Nestor Kirchner, and the new one, his wife Cristina Kirchner, elected in 2007. These elections confirm in polls the hegemony hijacking that obtained those who beard the ethical denunciation of the former regime into the Peronist party. 
The distance between the model theory and practice puts into perspective the aim of public debt clearing that would ensure long term growth. The constrained discretion norm is lacking on the transparency of official statistics on inflation and on public debt. The indicators hide the possibility of a risk of system. The restoration of ethical confidence is sullied by the same limits than the former model to establish a distributive compromise that does not reproduce the cycle of public debt crisis.

\subsubsection{A DISTRIBUTIVE COMPROMISE SHAPED ON THE GROUND OF ETHIC AND VALIDATED BY MACRO-ECONOMY}

The aim of maximizing job creation is the nodal point of the interdependence between the functional forms of money.

Coordination follows the constrained discretion norm. This justifies itself in the neo-structuralism approach by new structural characteristics of the economy. Following its opening, employment depends on the maintenance of a competitive exchange rate and on public debt-clearing (Frenkel, 2005). This macroeconomic policy of employment gives way to a discussion of possibilities to recast citizenship in "globalized" economies by moving away from the neo-liberal reconfiguration of social protection forms (Novick and Perez Soto, 2008)(20).

The essential part of inflation in the (very relative) conciliation of interests expresses itself in a permanence of distributive conflict weakening ethical and hierarchical confidences. The distributive conflict is only softened by employment progress. After four years of high growth, real salary only reaches its previous lowest level since 1960, the one to which it had plunged in the 1989 hyperinflation. On the other hand, from 2004, the profit rate exceeds its highest level since 1960, reached in 1996, and continues then its ascent. In the 1991/1994 growth phase, the salary rate had barely set up to the level of 1982 and 1989 previous floors (figure 2), resulting, among other factors, from inflation peaks. The curve of sharing of revenues between the occupied population income and gross operating surplus clearly shows the lowering trend of labor revenues' share, beyond some cyclical reversals effects $^{(21)}$.

The well more pronounced rise of the profit rate as compared to the salary rate in the crisis' way out explains the importance that still re-covers the empowerment of the poor thematic in distributive conflict management. The analyses quoted above of clienteles power in the policy of assistance to the poor (Lo Vuolo, 2007; Svampa, 2007) demonstrate its permanence but nothing proves its efficiency in generating a new consensus regarding social justice.

(20) The analysis of the place of employment in government policy opposes however various macroeconomic approaches, not to mention the one of the IMF. On the basis of the former structuralism model revision, it is showed that the growth of employment margins according to the exchange rate are reversible and that they would not indicate thus a structural change of the growth regime because of the opening but only its conjuncture effects (Keifman, 2007). Furthermore, the current macroeconomic policy is analyzed as a perpetuation of the social regulation inherited from the convertibility regime, what equally puts into perspective the hypothesis of a structural change that would authorize a full-employment policy viable in the long term (Lo Vuolo, 2007).

(21) One must recall that Argentina was until the end of the 1970 s a salary society comparable to some European countries. It is without doubt the only case of a division by two, since then, of the share of labor incomes. 
Figure 2 - Revenues functional distribution

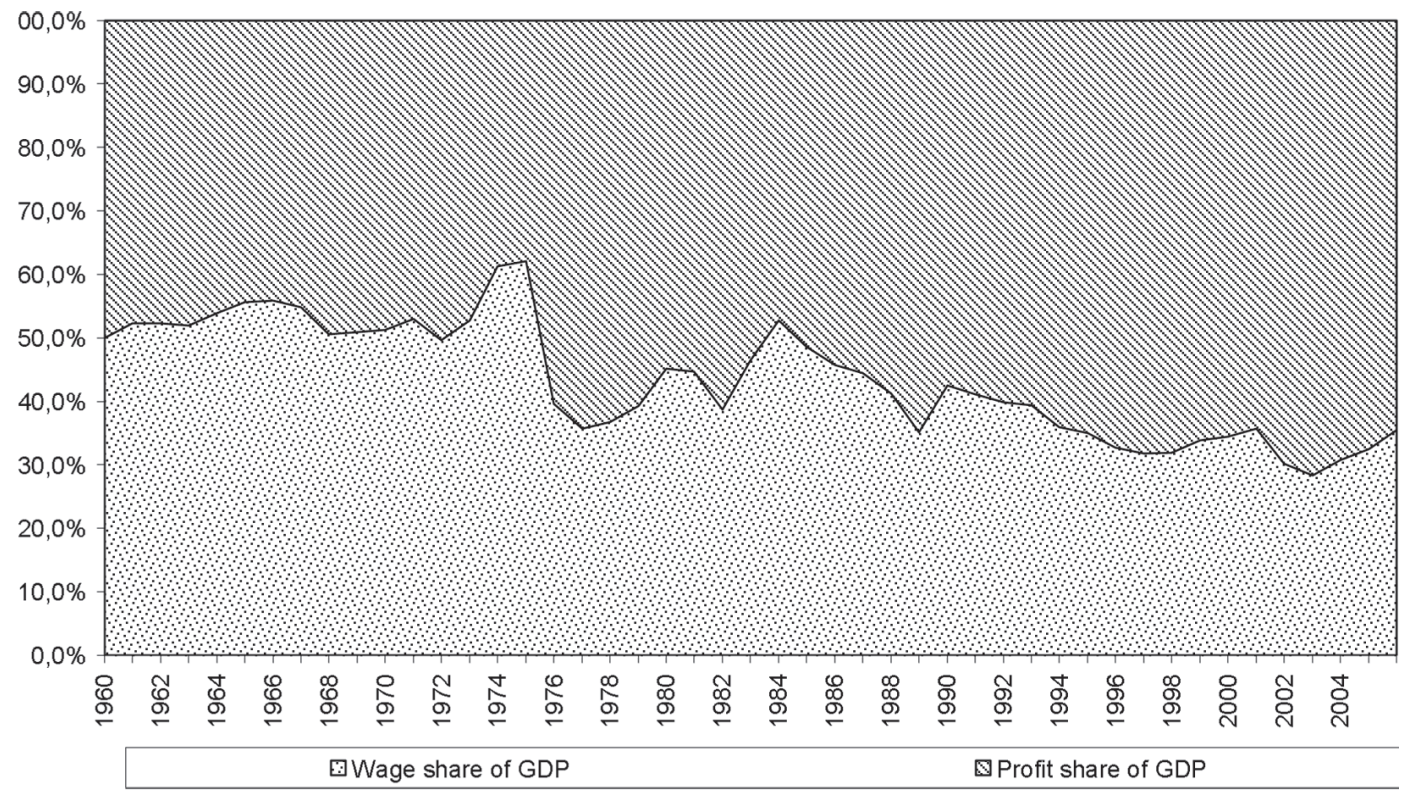

Source: CIEPP (2009), data CEPED (2007), Llach et Sanchez (1984), CEPAL (1991) and Ferreres (2005) (Profit share of GDP includes autonomous agents).

The restoration of ethical confidence has in any case been performed on numerous registers. We will only mention here those more representative. Criticism of the former economic policy seems to have been the favored ground of a new representation of general interest that the system of account should convey. Pesification leads to conflicts between the executive and the courts, devoted to the highest judicial level the monetary range/scope of a national restructuring. The judgments that decided in favor of demands for more advantageous conversion of some assets were invalidated by the Supreme Court, after several of its members who had been compromised under the previous regime were replaced.

We cannot, however, conclude that the uniqueness of the monetary fact is firmly established in collective action. The conciliation of economic interests through the system of relative prices raises the question of the (either or not) sustainable character of economic regulation from the point of view of inflation and the management of the public debt. The restoration of ethical confidence in money does not necessarily lead to a common vision of national development.

This limit did not come to bear in the crisis' exit because the short and medium term growth perspective allowed the re-establishment of a money market and ensured nominal anchorage, besides a fast reduction of unemployment and the funding of social spending. From a chronological viewpoint, the crisis' exit is sketched on the ground of ethical confidence, which re-establishes the interaction between the instituted and objectified states of money: the monnayage of debts limits the effects of the repeal of the convertibility law on banks and enterprises' balance-sheets. This limit to balance sheets deterioration, added to the limit on foreign competition set by devaluation and the fact that its inflationary effects are passed onto prices and not on salaries generate the revival of profits. These 
consolidate the private and public debt-clearing. Growth ensures nominal anchorage of relative prices. The monetary cautious objective of authorities in the distributive conflict administration is going to quickly find its limits, which the revival of inflation in 2007 points out. Caution appears, moreover, unconfirmed from a public debt management viewpoint.

\subsubsection{The Limits OF CONFIDENCE AND THE RENEWAL/CONTINUATION OF SYSTEMIC RISK}

The macro-economic link between public debt administration and price controls develops through three measures that demonstrate the difficulty of establishing an effective social pact: 1 / an administrative fixing of public tariffs which entailed investment insufficiency in the sector, particularly regarding energy and transport; 2 / the negotiation (revealing itself inefficient) of numerous prices, particularly the ones regarding oligopolies sectors; 3 / the regulation of prices of exportable food goods through the fixation of export quotas for products which domestic consumption is raised in a question of national sovereignty.

The margins of the prices control regime are restrained on macroeconomic level because inflation is the condition of maintenance of «desired» profit margins confronted with wage pressure being fed by a head-on conflict in agricultural price regulation by the export tax or quota. Now, fiscal revenues from exports become a macroeconomic determinant of inflation. The profit margins are a function of inflation and of the growth rate, which is conditioned by a budget surplus that the maintenance of exchange rate requires. Ceteris paribus from an external viewpoint, macroeconomic equilibriums were not guaranteed and the new situation brought by the global crisis threatens to worsen the budgetary problem. This one will probably not be linked to the issuance of public debt for sterilization of currencies repurchase, that has limited up to now the exchange rate appreciation, but at budget cost related the postponement clauses of its amortization and that can imply as well indexation clauses or the debt 's component drawn in currencies.

Before addressing this point in more details, one must report that the difficulties of price control lead to a challenge to the official index since $2007^{(22)}$, especially by numerous statisticians, including the employees of the institution (INDEC) responsible for its calculus. The credibility of the economic policy is thus called into question, not that much because of the absence of a social pact, but because this absence is in fact the very condition of a distributive compromise by default which seems the only possible. It explains the accommodating feature of issuance policy, to which the government is constrained.

Negative, or close to zero, real interest rates are not the way to a credit revival. Choices in monetary policy are a validation of margin behaviors. Indeed one has to note that the recovery of the economic level of liquidity has permitted an increase in real profit rate average index of around 50\% between 2001 and 2006 (figure 1), which offsets devaluation while wages remain at their devaluated level. Through the new regulation of the monnayage of debts, that asymmetrical pesification and the exchange regime have established, the system of account uniqueness combines three implicit units of account.

(22) The official rate fluctuates around $10 \%$ and others around $20 \%$ since 2007 . The distributive stake of the official rate is particularly important in the negotiation of the civil service salaries and of many others social benefits, beyond the service and the liquidation value of numerous titles. 
The devaluated peso draws all prices but it enables relative prices that, at minimum, compensate devaluation through mark-up and indexation in the respective calculus of expected profits and financial promises.

The threat that a real inflation higher than the official index devalues public debt was thwarted by its indexation. The starting justification to serve the debt according to the economic growth rate was in fact the source of an excellent return. One must note that the profitability of the financial system has rested even more on titles than in the currency board regime (CIEPP, 2009). The analysis of the stock and service accountability of public debt raises the question of the sustainable character of financial promises.

\section{Simulation of the implicit cost to stock/flow adjustments of public debt}

$$
\text { (Cf. Lo Vuolo and Seppi, 2008) }
$$

Accordingly to data published by the "Boletin Fiscal", the net stock of debt of Central Administration lowered from $140 \%$ to $55 \%$ of GDP between its peak of final 2002 and the end of 2006. Some other official documents, less mediated, provide a less optimistic vision. First, this drop does not take into account the debt in default towards creditors that have not accepted the new treasury bonds (12\% of GDP in 2006). It includes, on the other side, the credence on provinces corresponding to their default debt with the central administration. The credence in question represented, at the end of $2006,65 \%$ of central administration's assets and $8.5 \%$ of GDP. Second, the lowering of the stock hides other types of future potential flows that fiscal experts commonly name "skeletons in the closet". The expression refers to liabilities non registered in state's current financial balance from the moment that their settlement is conditional (loan guarantees of public enterprises, for example). The transparency of public accounts equally seems arguable, on this ground, regarding the postponed liabilities of bonds issued in exchange of the default debt or of the new bonds. The ones and the others imply a potential budget cost that can be, among other factors, accorded to an indexation to inflation or to GDP or even to an exchange rate, if they are drawn in a currency. The simulated calculus of these implicit costs, on the basis of the Ministry of economy's data, indicates an impact on the Budget financial performance that would have signified an increase in the debt stock which represents, in average 3.96\% of annual GDP between 2002 and 2006 or, concerning accumulated payments, 20\% of GDP. This increase shares out almost equally between the indexed to GDP coupons' increase and the capitalized interests + indexation to inflation.

The progression of national saving has covered the one of investment and negative foreign saving. However, the decline in current net stock of public debt that national accounts displays does not allow to conclude, as the Ministry of economy may has done (Mecon, 2005), that Argentine State was engaged in a process of debt-clearing that reduces the future need for foreign funding.

The potential future cost of public debt does not prove per se that a new systemic crisis, linked to public debt, would be inevitable. The above simulation put nevertheless in doubt that its possibility would be neutralized by the accumulation of exchange reserves and the flexibility of economic policy. There is, in this sense, an ignorance of the possibility of a risk of system. 
In sum, the hierarchical confidence may have been re-established and guaranteed until 2007 through methodical confidence because the monetary regime was able to administer the economic climate maximizing a growth based on investment funding by growing profits. Both forms of confidence are vulnerable because ethical confidence remains characterized by the absence of a long term vision of national development that weakens macroeconomic equilibriums. This fragility expresses itself particularly in the weakness of financial intermediation between households' saving and investment, indicated by the insignificant rise of credits share in the financial system total asset ${ }^{(23)}$. In the absence of a national development vision, by which ethical confidence could spring hierarchical confidence, the former is challenged since the official rate of inflation (and thus the implicit exchange rate target) is no longer credible.

The consistency between functional forms of money is thus precarious. Since the system of payment restoration - made concrete through the private debt-clearing and the reduction of media ratios of public debt to GDP and of the service of public debt to GDP, methodical confidence is assured. The existing distributive compromise is not the guarantee of long term growth. This monetary regime validating margins' behaviors testifies to, along with the weakness of credit to the economy, a lack of ethical confidence. The debt-clearing of the state, a key variable of the growth regime, is uncertain, and its moral scope is to be caught out. Creditors of public debt, guilty of moral hazard have finally seen their punishment at least alleviated by the reassurance of their incomes' promises through the indexation clauses of new titles.

Table 2: The sources of confidence in a money with «competitive and foreseeable» exchange rate 2002-2007

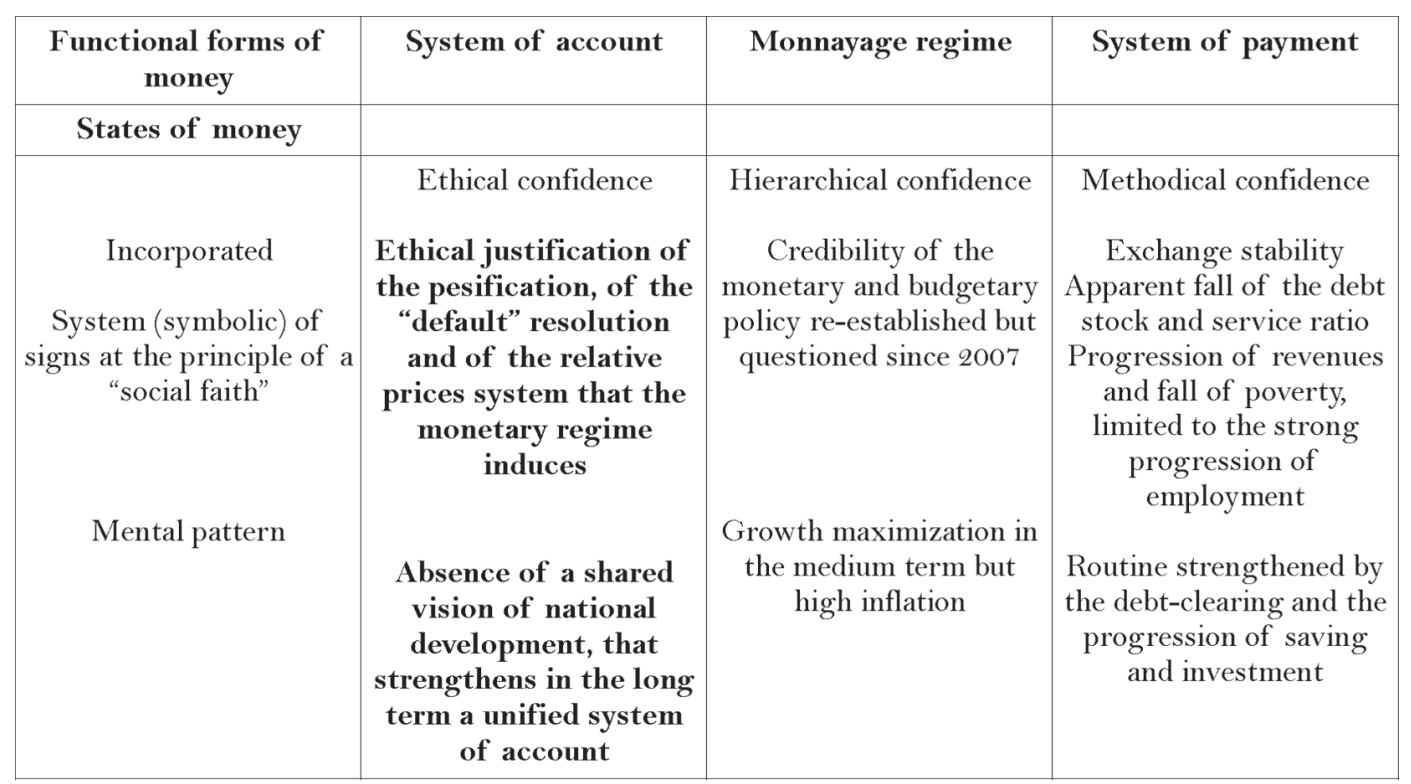

(23) For more details on the analysis of macroeconomic correlations of investment, saving and repartition, see Lo Vuolo and Marques Pereira, 2009. 


\begin{tabular}{|c|c|c|c|}
\hline $\begin{array}{l}\text { Institutionalized } \\
\text { System (politic) of } \\
\text { subjects in action in the } \\
\text { setting/framework of a } \\
\text { sovereignty }\end{array}$ & $\begin{array}{l}\text { Reunification of the } \\
\text { monetary territory } \\
\text { Control of the } \\
\text { inflationary effects of the } \\
\text { repeal of the } \\
\text { convertibility law but not } \\
\text { of the structural } \\
\text { distributive conflict }\end{array}$ & $\begin{array}{c}\text { Precarious distributive } \\
\text { compromise implying } \\
\text { an inflationary } \\
\text { monetary regime }\end{array}$ & $\begin{array}{l}\text { Payments in a single unit } \\
\text { of account are feasible } \\
\text { thanks to an } \\
\text { accommodating } \\
\text { monetary policy and to } \\
\text { the indexation of public } \\
\text { titles newly issued }\end{array}$ \\
\hline Collective action & $\begin{array}{l}\text { Absence of long term } \\
\text { anticipations and } \\
\text { formation of the risk of } \\
\text { system in the } \\
\text { accountability of public } \\
\text { debt }\end{array}$ & $\begin{array}{c}\text { Questionable public } \\
\text { accountability and } \\
\text { questioned } \\
\text { administration of } \\
\text { relative prices in the } \\
\text { absence of a social pact }\end{array}$ & $\begin{array}{l}\text { Inflation due to profit } \\
\text { margins } \\
\text { Limited financial } \\
\text { intermediation }\end{array}$ \\
\hline $\begin{array}{c}\text { Objectified } \\
\text { System (economic) of } \\
\text { objects enabling the } \\
\text { circulation - renewal of } \\
\text { debts }\end{array}$ & $\begin{array}{l}\text { The Argentine peso is re- } \\
\text { established as emblem of } \\
\text { the sovereign authority } \\
\text { of a community of } \\
\text { account but financial } \\
\text { indexation }\end{array}$ & $\begin{array}{l}\text { The nominal anchorage } \\
\text { of debts depend on an } \\
\text { exchange regime said to } \\
\text { be "competitive and } \\
\text { foreseeable", which is } \\
\text { questioned since } 2007\end{array}$ & $\begin{array}{l}\text { Indexation of the } \\
\text { public debt and } \\
\text { postponement of its } \\
\text { service determine the } \\
\text { differences of access to } \\
\text { the means of payment } \\
\text { and thus the repartition } \\
\text { of revenues }\end{array}$ \\
\hline Valuation principle & $\begin{array}{c}\text { The Argentine seal and } \\
\text { signature are dependent } \\
\text { on the lack of knowledge } \\
\text { of the systemic risk }\end{array}$ & $\begin{array}{l}\text { The exchange regime } \\
\text { and the budget surplus } \\
\text { have guaranteed the } \\
\text { increase of profits and of } \\
\text { financial gains linked to } \\
\text { the public debt }\end{array}$ & $\begin{array}{c}\text { Limited control of the } \\
\text { inflation, official index } \\
\text { questioned }\end{array}$ \\
\hline
\end{tabular}

\section{Conclusion}

The conception of money as a total social fact permits a positive explanation of the financial sudden reversals instead of the pure normative one in its neoclassical interpretation. The general lessons of this crisis and its way out are than rather different.

1. Sudden reversals of anticipation that triggered the crisis are the result of illusory promises of revenues in the long term. In the 1990s, this illusion was not the product of an individual «irrationality» or a non functional "reforms forum" but rather the result of a theory that based in the possibility to neutralize money but was not supported by big national economic groups. In and since the end of the crisis, anticipations seem limited to short and medium term.

Since money matters in the neoclassical theory only in the short term as policy objective - insure its neutrality, the risk of system that public indebtedness bears cannot be considered because the long term is a deduced normative vision of growth based on the quality of institutions.

2. The Argentine contingency of systemic risk, stressed above, stems from the toughening of a distributive conflict. It is expressed in the rejection of the indexation of salaries to productivity gains and a valuation of capital implying public indebtedness. All 
this only makes it a particular example of the symbolical performance of neo-quantitative theory of money as an intellectual referent of a collective cognition that makes money a veil, not of relative prices - they could not be set without it, but of social relationships that it enables to naturalize as expression of individual choices.

One must note that the strong growth of economic buoyancy and employment in the short term has not been sufficient to re-establish the ability of money to naturalize social relationships. In this regard, the outcome of the Argentine crisis already presents the ethical ground of the way out of the financial crisis in which the world is plunged today. The Argentine experience points out the limit to bank rescuing and pump-priming that do not consider the financial indebtedness regime. Could it be that the long term illusion that the quantitative theory of money was able to maintain be restored, as it was in Argentina, through an ethical debate linked to moral hazard and the empowerment of the poor. If such is the case, the history of the risk of system ignorance does not appear to be over.

\section{Bibliography}

AGHION, Philippe, COHEN, Élie and PISANI-FERRY, Jean. Politique économique et croissance en Europe, Rapport CAE n. 59, Paris: La documentation française, 2004. Avaiable in: <http:// www.cae.gouv.fr/spip.php?article54> Access in: 20 feb. 2011.

AGLIETTA, Michel and ORLÉAN, A. La monnaie, entre violence et confiance, Paris: Odile Jacob, 2002.

AGN, "Estudio Especial sobre Administración de pasivos del Estado Canje Default 2005". Documento Técnico n. 26. Gerencia de Control de la Deuda Pública, 2006. Avaiable in: <www.agn.gov.ar> Access in: 12 feb. 2011.

AMABLE, Bruno, BOYER, Robert, LORDON, Frédéric, "L’ad hoc en économie: la paille et la poutre", in D'AUTUME, Antoine and CARTELIER, Jean (Rds.), L'économie devient-elle une science dure?, Paris: Economica, 1995. p. 267-290.

ARROW, Kenneth. "Methodological Individualism and Social Knowledge", American Economic Review, Volume 84, Issue 2, 1994, p. 1-9.

BASUALDO, Eduardo. Estudios de historia económica de Argentina desde mediados del siglo XX a la actualidad, Buenos-Aires: Siglo XXI, 2006.

BLAUM, Luíz. "Le cas Argentine revisité, de l'utopie libérale au retour de la politique". Revue Tiers Monde, n. 189, 2007, p. 135-154.

BOYER, Robert. "La crisis argentina pone a prueba las teorías económicas contemporáneas" en BOYER, Robert and NEFFA, Julio César (Eds.). La economía argentina y sus crisis (1976-2001): visiones institucionalistas y regulacionistas, Buenos Aires: Miño y Dávila / CIEL/CIEPPE / Institut CDC pour la recherche, 2004. p. 695-707.

CEPAL. Proyecto revisión de las cuentas nacionales y de la distribución del ingreso; informe final. Buenos Aires: CEPAL, 1991.

CEPED, 1987-1992 datos no publicados, en base a EPH y Censos de Población, Centro de Población, Empleo y Desarrollo, Instituto de Investigaciones Económicas, Facultad de Ciencias Económicas, Universidad de Buenos Aires, Buenos Aires, 2007. 
CIEPP. Base de datos de la investigación “Ahorro, Crecimiento y Distribución (1991-2006)", BuenosAires, 2009.

CALVO G., IZQUIERDO, A. and TALVI, E. Sudden Stops, the Real Exchange Rate and Fiscal Sustaintability: Argentina's Lessons, BIRD, 2003.

DAMILL, Mario, FRENKEL, Roberto and RAPETTI, Martin. "La deuda argentina: historia, default y restructuración”, en BOYER, Robert and NEFFA, Julio César, (eds.), Salida de crisis y estrategias alternativas de desarrollo, Buenos Aires: Miña y Dávila. Institut CDC pour la recherche/ CEIL-PIETTE, 353-399, 2007.

DORNBUSCH, Rudiger and EDWARDS, Sebastian. La Macroeconomía del Populismo en América Latina. Mexico: Fondo de Cultura Económica, 1992.

EICHENGREEN, Barry and HAUSMANN, Ricardo. Other's People Money, Debt Denomination and Financial Instability in Emerging Economies. Chicago: University of Chicago Press, 2005.

FERRERES, Orlando (Ed.). Dos Siglos de Economía Argentina (1810-2004): Historia Argentina en Cifras, El Ateneo y Fundación Norte y Sur, Buenos Aires, 2005.

FELDSTEIN, M. "Argentina's Fall: Lessons from the Latest Financial Crisis", Foreign Affairs, Vol. 81, p. 8-14, 2002.

FRENKEL, Roberto. "Las políticas macroeconómicas, el crecimiento y el empleo", Capítulo II de OIT, Oficina Internacional del Trabajo Generando trabajo decente en el Mercosur. Empleo y estrategia de crecimiento, OIT, Oficina regional para América Latina y el Caribe, Oficina de la OIT en Argentina. Buenos Aires, 2005.

GALIANI, S., HEYMANN, Daniel and TOMMASI, M. "Great expectations and hard times: the Argentine convertibility plan", Economia: Journal of the Latin American and Caribbean Economic Association, vol. 3, 2003, p. 109-160.

KEIFMAN, Saúl. "Le rapport entre taux de change et niveau d'emploi en Argentine: Une révision de l'interprétation structuraliste”. Revue Tiers Monde, n. 187, 2007, p 93-112.

KRUEGER, Ann. "A New Approach to Sovereign Debt Restructuring". Washington: International Monetary Fund, 2002.

KYDLAND, Finn and ZARAZAGA, Carlos. Crisis Prevention and Resolution: Lessons from Argentina, NBER, Conference Argentina Crisis, July 1 $7^{\text {th }}$, 2002.

HAUSMANN, Ricardo and VELASCO, Andrés. The Argentine Collapse: Hard Money's Soft Underbelly, mimeo, Harvard University, April 26, 2002.

HEYMANN, Daniel, "Comportamientos inconsistentes y perturbaciones macroeconómicas”, Anales de la Academia Nacional de Ciencias Económicas, 2002.

HEYMANN, Daniel (2006). "Buscando la tendencia: crisis macroeconómica y recuperación en la Argentina”, Serie estudios y perspectivas (Oficina Buenos Aires), n. 31, Buenos Aires: CEPAL.

JACOPIN, Pierre Yves and PUEX, Nathalie (2002). "Misères de la monnaie, monnaies de la misère. La crise monétaire vue par les habitants d'une villa miseria de la banlieue de Buenos Aires". Journal des anthropologues, n. 90-91, Association française des anthropologues, p. 25-53.

LLACH, Juan José and SÁNCHEZ, Carlos. "Los determinantes del salario en la Argentina. Un diagnóstico de largo plazo y propuestas de políticas”, Estudios n. 29, Año VII, IRREAL, Córdoba, 1984.

LAKOMSKI-LAGUERRE, Odile. "Money and Credit in Schumpeter and Hawtrey", Annual Conference, ESHET, 2004. 
LO VUOLO, Rubén. "Argentine, les leçons d'une sortie de crise". Revue Tiers Monde, n. 187, p. 13-33, 2007.

LO VUOLO, Rubén and SEPPI, Fernando (2008). La falacia del desendeudamiento del sector público en la Argentina, Documento de trabajo n. 61, CIEPP

LO VUOLO, Rubén and MARQUES PEREIRA, Jaime. Las condiciones de estabilidad del crecimiento, el ahorro y la distribución del ingresso. Relato de investigación para el Institut CDC pour la recherche, CIEPP, 2009. Available in:<http://www.u-picardie.fr/CRIISEA/> Access in: 5 mar. 2011.

MAIA, José Luíz and NICHOLSON, Pablo. "El Stock de Capital y la Productividad Total de los Factores en Argentina”. Dirección Nacional de Coordinación de Políticas Macroeconómicas, Secretaría de Política Económica, Argentina, 2001.

MUSSA, Michael. Argentina y el FMI, Del triunfo a la tragedia. Buenos Aires: Planeta, 2002.

NEFFA, Julio César. "La forma institucional relación salarial y su evolución en la Argentina desde una perspectiva de largo plazo", in BOYER, Robert and NEFFA, Julio César, (eds.), La economía argentina y sus crisis (1976-2001): visiones institucionalistas y regulacionistas, Buenos Aires: Miño y Dávila/CIEL/CIEPPE/Institut CDC pour la recherche, 2004, p. 105-150.

NOVICK, Marta, and PÉREZ SOSTO, Guillermo (eds.). El Estado y la reconfiguración de la protección social, Asuntos pendientes. Buenos Aires: Siglo XXI, 2008.

PALERMO, Vicente. "Melhorar para piorar? A dinâmica política das reformas estruturais e as raízes do colapso da convertibilidade”, in Sallum, B. (ed.), Brasil e Argentina hoje, Política e Economia, São Paulo: Edusc, 2004.

PRESCOTT, Edward and KYDLAND, Finn. "Business cycles: real facts and a monetary myth", in MILLER, Preston (ed.), The Rational expectations Revolution. Readings from the Front Line, Cambridge (Mass.): The M. I. T. Press, p. 307-334, 1994.

RANCIÈRE, Jacques (1995). La mésentente. Politique et philosophie. Galilée, Paris.

RODRIK, Dany. Nations et mondialisation. Les stratégies nationales de développement dans un monde globalisé. Paris: La découverte, 2008.

ROIG, Alexandre. "La 'création' d'une monnaie éternelle, genèse de la convertibilité en Argentine", in LORDON, Frédéric, Conflits de pouvoirs dans les institutions du capitalisme. Paris: Sciences Po Les Presses, 2008. p. 91-137.

SAMUELSON, Paul. "An Exact Consumption-Loan Model of Interest without the Social Contrivance of Money", The Journal of Political Economy, Vol. 66, n. 6, p. 467-482, 1958.

SCHUMPETER Joseph. Das Wesen des Geldes, Goettingen: Vandenhoeck \& Ruprecht, 1970.

SGARD, Jerôme. Le currency board: ce qu'on en dit après et sa fin tragique. CEPII/Université Paris Dauphine, Paris, 2004.

SVAMPA, Maristella. Les frontières du gouvernement de Néstor Kirchner: entre aspiration au renouveau et consolidation de l'ancien, Revue Tiers Monde, n. 187, 2007.

TIZZIANI, Ana. "Du péronisme au populisme ou la conquête - conceptuelle — du gros animal populaire”, Revue Tiers Monde, n. 187, p. 175-194, 2007.

THERET, Bruno. "Les trois états de la monnaie". Revue économique, vol. 59/4, p. 813-841, 2008.

THERET, Bruno (éd.). La monnaie révélée par ses crises. Paris: Editions de l'EPHESS, 2007. 
THERET, Bruno and ZANABRIA, Miguel. L'expérience des monnaies provinciales dans la crise de convertibilité, une comparaison de leurs succès et de leurs échecs visant à mettre à jour les conditions d'un régime de monnayage véritablement fédéral, communication au colloque "Analyses et pratiques du développement: enjeux et diversité des approches de la francophonie”, UPJV/CRIISEA, Amiens, octobre 2006.

THERET, Bruno. "L'effectivité de la politique économique: de l'autopoièse des systèmes sociaux à la topologie du social”. L'Année de la régulation, Vol. 3, p. 127-168, 1999. 